\title{
СЛИКАТА ЗА ДРУГИОТ ВО „ЗМИСКИ ВЕТЕР“ И „ЕГЕЈЦИ“
}

\author{
Весна Кожинкова \\ СОУ Гимназија „Славчо Стојменски“ Штип \\ v_kozinkova@yahoo.com
}

Науката за литературата и компаратистиката ја развија имагологијата како посебна дисциплина која ги проучува сликите за gруг̄ииее. Најчест облик на сликата на gруг̄иоти е стереотипот, во последните децении многу користен термин во сите општествени теории. Стереотипот станува средство за препознавање, етикетирање, ориентирање, потврдување и вреднување. Во историјата на изучувањето на стереотипите најмногу внимание е посветено на етничките и на културните стереотипи. Во нашата културна и книжевна историја посебно место имаат стереотипите за Македонците жртви на егзодусот за време на Граѓанската војна во Грција. Со текот на времето и низ времето Егејците и „егејството“ воопшто добиваат одредени идеолошки содржини, така што тие прераснуваат во еден своевиден мит кој може да има позитивна или негативна употреба во зависност од одреден актуелен контекст. Позитивната употреба на тој мит се гледа преку протежирање на т.н. егејски теми од реномирани уметници кои потекнуваат од тој дел на Македонија. Негативната употреба се гледа во фактот на последиците од негативните стереотипи за Егејците, за нивната неподобност за вршење на јавни општествени дејности, за нивната сомнителност во одреден политички контекст.

Клучни зборови: слики, стереотипи, другост, култура, историја 


\title{
THE IMAGE OF THE ‘OTHER’ IN THE SNAKE WIND AND THE AEGEANS
}

\author{
Vesna Kožinkova \\ High school Slavčo Stojmenski, Štip \\ v_kozinkova@yahoo.com
}

Literary science and comparative literature have developed imagology as a separate discipline dealing with the study of the images of the Other. The most common form of an image of the Other is the stereotype a term that has found broad use in all social theories during recent decades. The stereotype becomes a means for recognition, labeling, orientation, validation and evaluation. In the history of studying stereotypes, ethnical and cultural stereotypes have received the greatest amount of attention. In our cultural and literary history, a special place is reserved for the stereotypes of Macedonian victims exiled during the Civil War in Greece. In time, and throughout time, the Aegeans and "Aegeanism" in general have received certain ideological contents, transforming them into a myth which can have either positive or negative uses depending on the context. The positive interpretation of that myth can be seen through the preferential treatment of so-called Aegean themes found in the works of renowned artists coming from that part of Macedonia. The negative interpretation can be seen in the factuality of the negative consequences against Aegeans stemming from negative stereotypes about them, such as their alleged unsuitability to do public work, or viewing them as suspicious in certain political contexts.

Key words: images, stereotypes, otherness, culture, history 
Другоста е комплексен феномен кој постојано го привлекува вниманието на научниците не само во книжевно-теориската практика туку и во рамките на културолошките, филозофските и социолошките проучувања. Причината за тоа лежи, веројатно, во сознанието дека gруг̄иой се наметнува како еден од основните елементи на човековата егзистенција. Фројд во „Неугодното во културата““ (Freud 1996) вели: „Луѓето страдаат од три причини: нивното тело е трошно, постојат природни непогоди: земјотреси, поплави; затоа што природата е во безинтересен однос кон луѓето и затоа што другите луѓе те прават несреќен“. Притоа додава дека првите две се реални и објективни извори за несреќата на луѓето, додека „другите луѓе“ ги третираме едвај како субјективен чинител. Меѓутоа, вели Фројд, ние страдаме само и исклучиво заради другите-тоа е фрапантната и застрашувачка сила дадена во рацете на gруг̄uо $\bar{u}$. Овој труд ќе се обиде да ја даде сликата на gруг̄uйе, во случајот бегалците од егејските дел на Македонија и нивното место во рамките на македонската културна и политичка средина по нивното принудно и трајно напуштање на вековните огништа. Трудот започнува со теориската рамка на истражувањето, во рамки на референтната литература, а за апликативен материјал е одбрана историско-документарната проза „Егејци“ од Кица Колбе и романот „Змиски ветер“ од Ташко Георгиевски

„Како човек ја проценува својата околина?“ е прашањето кое германскиот невролог Волф Цингер (си) го поставува на 43. Конгрес на германските историчари. Процесот на когниција, Цингер го дава од невробиолошко гледиште објаснувајќи дека од мноштвото впечатоци и дразби на кои е изложен човекот во секојдневниот живот, ги одбира и ги селектира само оние кои му се неопходни за да преживее во комплицираните услови на битисувањето. Од тие перципирани елементи создава сопствена кохерентна слика на светот врз основа на која создава една сопствена имагинарна карта слична на географската. На таа карта, на која подоцна ѝ е дадено името „ментална карта“, се внесуваат сите податоци на перципираната околина во просторен, временски и во друг контекст. Менталната карта му овозможува на човекот да ја разбере околината во која живее, временски и просторно да се ориентира, да го најде својот идентитет и своето место во општеството и

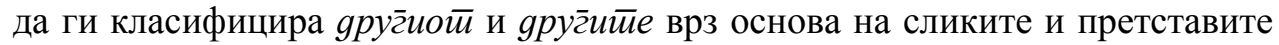
кои ќе ги изгради за нив и за нивната етничка, национална, верска и друга припадност.

Таа ментална карта станува слика за светот, слика за gруг̄иой/gруг̄uӣe, слика за себеси. Степенот на сличност на таа ментална карта со реалноста може да биде различен. Сличноста може да биде делумна, но не мора ни да постои. Нејзиното создавање е плод на личните симпатии, желби, наклонетости, но и плод на антипатија, омраза, индивидуални и колективни предрасуди и стереотипи. Како таква таа повеќе зборува за личноста која оценува, отколку за оценуваното. А кога зборуваме и мислиме на 
книжевноста како за специфична дејност на човекот, мислиме, пред сѐ, на нижењето на буквите како знаци и нивната улога во презентацијата на одредена култура и затоа Даниел-Анри Пажо за книжевноста зборува како за место во кое постојано се произведуваат слики на културата.

Заради тоа науката за литературата и компаратистиката ја развија имагологијата како посебна дисциплина или интердисциплина која ги проучува сликите за gруг̄иие. Нејзината актуелност упатува на погрешен заклучок дека таа е нова дисциплина. Можеби тоа е и оправдано ако се земат предвид сите трансформации кои ваквите проучувања ги доживеаја под влијание на развитокот на науката за литературата и другите науки: социологија, етнологија и историја. Имагологијата, како посебна компаративистичка дисциплина која ги проучува интеркултуралните односи во смисла на заемно набљудување, слика на самиот себе (auto-image) и сликата на gругиио $\bar{u}$ (hetero-image), настанува во Франција во 50-тите години на 20 век под името „проучување на слики и привиди“, а врз основа на идеите кои се развија неколку децении порано. Терминот не е книжевен, туку него првпат го имаат употребено психолозите. Во психоанализата терминот imago (лат. слика, лик) прв го воведува Јунг и со него означува слика на некоја значајна личност, мајка или татко, која постои во колективното несвесно. Од него терминот го презема Фројд и го проширува со тоа што со него се означува секоја важна личност, а не само личности од кругот на семејството. Потоа, зборот имагологија е изведен од психологијата на народите, за на крајот да го добие значењето слика на колективниот идентитет. Кон крајот на 60-тите години на 20 век овој термин е преземен од француските проучувачи на книжевноста и со него се означува туѓото во анализата на книжевните дела. Или како што ќе заклучи Катица К'улавкова: „една од најстарите компаратистички дисциплини која ги проучува сликите за Другиот“ (Ќулавкова 2007: 199). Во неа Даниел-Анри Пажо препознава еден интердисциплинарен концепт бидејќ е резултат на „истражувањата направени од етнолози, антрополози, социолози, историчари на менталитетите и сензибилитетите, коишто се зафаќаат со прашањата што се однесуваат на културите на 'другите', за другата природа, идентитетот, културната асимилација, губењето на културниот идентитет, културната отуѓеност“ (Пажо 2002: 102). Една најопшта дефиниција за имаглогијата е дека таа претпоставува проучување на слики и мислења за други народи и култури претставени низ најразлични облици во литературата.

Клучниот збор во терминот е, секако, зборот image или сликата за gруг̄uой. Тука, во прв ред, не се мисли и не се очекува дека тоа се вистинските, реалните слики за народите и културите, туку за сликите кои тие едни за други ги имаат оформено и претставено во уметничките дела. Значи, станува збор за конструкции кои навлегуваат во сферата на имагинарното. Послободно протолкувана, имагологијата претставува замислување на другите култури и народи, формирање судови за нив и споредување на себеси co нив. Затоа поимот imago е заменет со поимот mirage - привид, 
фатаморгана, затоа што, во крајна линија, сликата за яруг̄ииее никогаш не е вистинската. „[С]екоја слика задолжително е лажна“, заклучува Пажо, затоа што таа е превод на стварности со помош на зборови. Таа не е аналогна на стварноста. Но имагологијата нема да се занимава со утврдување на степенот на искривеноста на сликата, туку ќе се обиде да ја открие причината за создавање на такви искривени, деформирани слики за gругийе оптоварени со многу предрасуди, клишеа и стереотипи. А компаративистот/имаголог има многу сложена и одговорна задача. Тој треба да ги земе предвид истражувањата на соседните истражувачи, не со цел да го занемари книжевното проучување или непотребно да го прошири доменот на своето проучување туку да ги спореди своите методи со методите на другите и, пред cè, ,,со сликата наречена 'книжевна' за паралелните и современи сведоштва, за претставувањата пренесени преку печатот, паракнижевноста, филмот, уметностите“ (Пажо 2002: 102). Поточно, тој треба да нотира книжевно размислување во една општа анализа која се однесува на една или на повеќе култури. Како таква, книжевната слика станува целост од размислувања и претставувања на gруг̄oӣo во постапка на книжевно приспособување и социјализација.

Пажо вака ја дефинира сликата: „Секоја слика произлегува од некое сознание, колку и незначително да е, на некое јас во однос на некој друг, на некое овде во однос на некое таму“ (Пажо 2002: 103). Едно вакво толкување на поимот нужно имплицира некакво растојание, некаков простор (општествен, културен, идеолошки, национален, родов). Тој простор е местото каде што на еден сликовит начин се дадени сите начини според кои некое општество се гледа себеси, размислува за себеси, мислејќи, сонувајќи за другото. Во извесна смисла сликата е јазик, второстепен јазик, паралелен co ,jас“ јазикот кој го гледа другиот, пишувајќи и зборувајќи за него. Уште повеќе сликата е и симболичен говор бидејќи „ова јас сака да каже другиот, ама велејќи другиот, $j a c$ се труди да го одрече и да се претстави самото себе“" (Пажо 2002: 105). Сликата има лингвистичка природа во смисла на Емил Бенвенист - таа преставува изложување и составување на одделни единици од кои секоја е знак и нивно етаблирање во рамките на една иста заедница. Гледајќи на сликата како симболичен говор, задачата на имагологијата станува покомплексна бидејќи таа треба да разбере и протолкува зошто и како сликата станала симболичен јазик, да ја разложи структурата на книжевниот систем и општествената вообразба како збир на такви слики.

Сликата за gруг̄uой се гради со помош на одредена лексика составена од т.н. клучни и сенишни зборови. Клучните зборови, според Пажо, се зборовите кои потекнуваат од земјата/културата која се набљудува и кои служат да се дефинира земјата/културата која се набљудува. Наспроти нив се т.н. сенишни зборови директно преземени од земјата/културата која се набљудува, но кои без превод се прелеваат во текстовите на земјата која набљудува. Тие зборови го градат писмото на gруг̄остй кое особено треба да води сметка за различностите и претопувањата. Во првиот случај gруг̄иот̄ го препознаваме 
како спротивен на jac, а во вториот како сличен. Како и да е, едно е сигурно, а тоа е дека сликата е превод на gруг̄иой, но во исто време и автопревод. Таа со изборот на писмото има задача да воспостави врска, однос или да развие став кон определена култура. Според Пажо (2002), постојат најмалку три суштински става или модели кои можат да се изградат во однос на другата култура.

Првиот суштински став е манијата. Тоа е состојбата кога туѓата стварност се смета за апсолутно надмоќна во однос на изворната култура. Изворната култура се смета за пониска, инфериорна во однос на туѓата. Последица од таквото гледање е негативната перцепција на изворната култура. Вториот суштински став е фобијата. Овој став е обратен од првиот бидејќи сега туѓата стварност се смета за подредена, инфериорна, вредносно негативна во однос на изворната култура. Единствен став кој е во состојба да воспостави рамноправен однос меѓу нас и gруг̄uйе е третиот став - филијата. Тоа е ставот кога туѓата стварност е видена, позитивно оценета и рамноправно учествува во изворната култура, која, позитивно оценета, е комплементарна со набљудувачката култура. Тоа е заемно познавање и признавање, критичка размена и дијалог меѓу еднаквите. Ако манијата е, симболички кажано, претпоставена смрт на $j a c$, фобијата симболичка смрт, отстранување на gруг̄uo $\bar{u}$, филијата го трасира патот на признавање на gруг̄uой жив покрај јас. Пажо размислува за постоење на уште еден, нов четврти став кој би се состоел во укинување на дијалогот за да им отстапи место на новите целости во една постапка на обединување или обновување на единството кое исчезнало со текот на времето. Такви целости тој препознава кај сите културни идентитети со префиксот йан-: панлатинство, пангерманизам, панславизам, но и космополитизам, интернационализам. Но, ваквиот став носи скриена опасност бидејќи во тие пан-целости тешко можат да се издвојат позитивните или негативните ставови на едни пан- наспрема други. Тука можат да се препознаат фобиите реинкарнирани, со последици кои далеку ќе ги надминат границите на една култура.

Најчест облик на сликата на gруг̄иоӣ е стереотипот. Кога во 1922 година го сковува овој термин, Волтер Липман нема намера да му даде пејоративно значење, какво што тој со текот на времето и употребата полека, но сигурно добива. „Образецот на стереотипот не е неутрален. Не е тоа само еден од начините во големата, блескотна и заглушувачка збрка на реалноста да се воспостави ред. Не е само пократкиот пат. Тој е сето тоа и многу повеќе. Тој е проекција во светот на нашите претстави за нашата вредност, нашата положба и нашите права. Стереотипите заради тоа се силно исполнети со чувствата коишто постојано ги следат. Тие се тврдините на нашата традиција, а зад нивните зидини ние и понатаму можеме да се чувствуваме сигурни на позициите кои ги заземаме“ “ ке истакне Липман. ${ }^{1}$ Во вака стокмената

\footnotetext{
1 Според Ричард Дајер https://alternativniglasovi.files.wordpress.com/2009/02/ricard-dajernovo.doc
} 
дефиниција, Липман истовремено ја истакнува нужноста и корисноста на стереотипите, но и сите ограничувања и идеолошки импликации кои тие ги произведуваат. За Даниел-Анри Пажо стереотипот е моќна форма на сликата, тој е знак кој несвесно упатува на едно единствено можно толкување, показател на еднозначното поврзување на културата на патот на одвојувањето од другите култури. Меѓутоа, факт е дека кога говориме за стереотип, говориме за еден релативно нов и нестабилен термин во последните децении многу присутен и користен во сите општествени теории. Но, од друга страна, пак, честата употреба придонесува за губењето на неговото значење првостепено поради немање прецизен референт, поради брзата замена на еден стереотип со друг и недоследноста во неговото користење. Кога неговата употреба е доведена до степен на еден вид „помодарска навика“, тој ја доживува судбината на сите актуелни термини: што повеќе искуства покриваат, толку повеќе ја губат прецизноста и јасноста.

И покрај кревкоста во значењето на терминот, сепак, најголем број истражувачи се сложуваат околу едно, а тоа е дека стереотипите претставуваат поедноставено прикажување, типизирање, шаблонизирање, генерализирање на појавите, групите, колективите. Неговото настанување, според Пажо, е последица на измешаноста на атрибутот и суштината кога атрибутот доаѓ на местото на суштината. Формата на стереотипот, значи, е придавска. Квалификативот, епитетот, придавката стануваат суштина. Оттаму и формулациите од типот: „таквиот народ е...“, „таквиот народ не е...“ претставуваат формулации во сегашно време на вонвременските суштини, формулации на едно блокирано време, знак на една блокирана култура, која, со оглед на неговата стандардизација, станува тавтолошка, постојано повторлива.

Стереотипот е сложен мисловен процес кој е во тесна врска со комуникацискиот. Тој предава најмал вид информација за најширока можна комуникација која се стреми кон обопштување. Всушност, како таков, стереотипот е согласност меѓу едно општество и еден упростен културен израз, резултат на една мисловна и јазична економија, „пократкиот пат“, како што забележува Липман. Во создавањето на стереотипот се гледа единството на човековата потреба да генерализира, шаблонизира, обопштува и човековата склоност кон стегнат израз, кон економичност во изразувањето. Меѓутоа, стереотипот, освен како слика за другите народи и култури, може да функционира, да се инсталира и во рамките на еден народ или култура. Таков е случајот кај нас во нашата историја со бегалците кои за време на граѓанската војна во Грција беа населени во веќе ослободениот дел на Македонија.

Македонците од Егејска Македонија поминаа една своевидна голгота во своите животи, што за последица има еден нарушен животен континуитет, едни прекинати животни биографии. Во едни изменети животни околности во кои репресијата станува секојдневие, тие се принудени да ги напуштат своите домови и да се населат во други места кои понатаму ќе мораат да ги 
именуваат со зборот дом. Својата позната и сакана средина мораат да ја заменат со нова, своите сакани и познати од својата околина ќе треба да ги надоместат со други. Нивните рути на движење се исти за сите, а секоја индивидуална и посебна за себе. Од Браилово, каде што е местото за запишување и идентификација, тие своите патишта ги продолжуваат понатаму во напуштените села, во напуштените куќи чии жители изумреле, во посебни делови од градовите, покрај пругите, покрај земјоделските комбинати, во своевидни егејски гета, во прифатилиштата за бегалци во Југославија, во напуштените села во Војводина, во детските домови во Романија, Полска, Чехословачка (Пановски и Лафазановски 2005). Секоја приказна е посебна, секоја болка има поинаква боја, а сите се вклопуваат со заедничката - траумата поради губењето на домот. Луѓето физички изморени, душевно осакатени очекуваат да наидат на разбирање, на сочувство од страна на другите од онаа страна на границата, од горе како што тие милуваат да речат, од оние кои ги нарекуваат и ги чувствуваат како свои. Пристигнуваат со отворени срца и уште на самиот почеток се судираат со обратното: недоверба, сомнение, отпор, па дури и отворено одбивање. Доаѓаат во средина како Егејци, збор што разделува, а не збор што сплотува (Колбе 1999).

Така се создал стереотипот на егејството како стигма, како обележаност и различност од другите, тукашните. Стереотипот станува средство за препознавање, етикетирање, ориентирање, потврдување и вреднување. И уште повеќе: тој е средство во процесот на формирање на ставовите и нивното востановување, незаобиколен елемент во секој колективен или индивидуален ангажман, но и најважно средство во воспоставувањето, распределбата и оспорувањето на моќта. Тој е средство со кое посилните, во случајот тукашните, си обезбедуваат културна супериорност, воспоставуваат културен империјализам, како замена или како продолжение на економскиот империјализам. Ексклузивното право да се создаде, да се одржи или да се промени некаква генерална претстава за другите, секогаш го имаат оние кои поседуваат воена, економска, политичка или симболична моќ. Тукашните, како што Егејците ги именуваа, во случајот ја имаат само таа симболична моќ. Токму затоа, посебно внимание се посветува на политичките (или идеолошки), културните и етничките стереотипи.

Политичките (идеолошки) стереотипи се директно зависни од политичките состојби и идеологијата на владејачките гарнитури. Со оглед на нивната политичка моќ и политичко влијание, овие стереотипи се цврсто инфилтрирани во обичноста на официјалните јазици и стилови така што ретко кој и ги препознава како стереотипи. Промената на идеологиите ја менува и коректноста на стереотипите. Некои од нив, оценети како пожелни, неопходни, потребни, академско легитимни се форсираат како корисни стереотипи, а сите други, кои се надминати, се цензурираат. Сведоци сме дека имиња на поедини региони и народи кои долго време се сметани за вредносно негативни се бришат или се заменуваат со други. Но, се поставуваат 
прашањата: Дали простата замена на имињата ќе влијае врз промена на претставите за нив? Дали оваа коректна реторика слична како онаа во која „црнец“ се заменува со „,афроамериканец“, ќе ја смени претставата за нив? Дали преименувањето на Балкан со Југоисточна Европа или со Западен Балкан ја менува претставата за овој регион и неговиот статус? Со други зборови, ваквата „коректна“ реторика ризикува да се претвори во реторичка маска со чија задолжителна употреба се легитимизира постоењето на стигмата и уште повеќе се потенцираат местата кои се чувствителни.

Така да се биде Eг̃eеu, може да биде пожелно или не во зависност од актуелната политичка состојба. Нивните приказни побудуваат малку интерес кај тукашните. „Треба да се замине далеку за да се најдат вистинските слушатели“ - резигнирано заклучува Колбе, размислувајќи за тоа на колкумина им ја има раскажано приказната за Егејците и приказната за нејзиниот татко, Ташо Барџиев. Целото доживување и целата претстава за нив од тукашните, таа најдобро ја илустрира со една анегдота од своето детство, која постојано се прераскажувала со шеговитост на самоутехата, но не без горчлива иронија. На прашањето на некој селанец кои се луѓето собрани покрај чешмата, селанецот лаконски одговорил: „Не се луѓе, Егејци се“. Ваквиот одговор најдобро го илустрира целокупното доживување на тукашните во однос на дојденците. Тоа се претставите кои остануваат живи и актуелни долги години потоа, тоа се стереотипите кои се мачат да ги разбијат и припадниците на третата, па и веќе на четвртата генерација бегалци кои живеат во Република Македонија. Самиот одговор на селанецот говори дека тоа се луѓе различни од нас. Одговорот ја потенцира разликата која е направена со самото нивно доаѓањ. Таа разлика најсуштински се гледа во самото име Eгејци - име кое не треба да прифаќа, туку да разликува. Стигмата се прави тука на местото кое треба да биде утеха и надомест за сето она што тие го изгубиле. Името Егејции станува стереотип со кој тие се препознаваат, се изделуваат, етикетираат и така се обележуваат во средината во која дошле. А таа средина, афиримирајќи се како супериорна, го има тоа ексклузивно право на етикетирање и воспоставување на симболична моќ врз оние кои таа ги афирмира како други, како различни и со тоа непожелни.

А тие, Егејците, постепено почнуваат да се навикнуваат на новото име. Тоа го прават во очекување и надеж дека ќе се вратат дома. Тоа го прават со горчлива меланхолија на сеќавањето за дома. Сеќавањето е местото на нивниот вистински живот. Тоа е нивното безбедно место на утеха. Се навикнуваат на новото име кога гладни просат по околните села, а дома ги оставиле полните амбари со жито и шталите со добиток. Се одsиваат на тоа име и кога селаните, тукашните, им ги пуштаат своите кучиња за да ги изгонат: „Од Пелагија и од Дора слушнал дека стопанот Никола ги насаскувал кучињата сосила да лајат и да завиваат откако слушнал дека неговата Дора се плаши од тоа. Додека тие лаеле тој излегувал ноќе и се смеел триејќи ги рацете“ (Георгиевски 1969: 72). 
Во историјата на изучувањето на стереотипите најмногу внимание е посветено на етничките и на културните стереотипи. Во последните децении ним им се пристапува од перспектива на т.н. културна интимност, термин кој го воведе Херцфелд (2004). Таа културна интимност ја сочинуваат тие т.н. сврзувачки особини на еден народ кои се повод за надворешна непријатност, од една страна, и внатрешна сигурност, од друга. Тие најчесто се однесуваат на замислените народни, односно национални вредности и суштини, специфични својства, на особености и разлики во однос на другите, во главно, соседите. И тука, со тој нов јазик повторно се тематизира приказната за националниот карактер и доследното истражување на неговите својства што е мотивирано од потребите на контекстот, „но сликите во главата““ како што првобитно се именувани стереотипите, всушност, никогаш не исчезнуваат. Во фактот за нивната трајност и постојаната потенцијална присутност се содржани агенсите за можна манипулација и ескалација во кризни периоди. Токму заради тоа, реафирмирањето на првобитното значење на стереотипот е од пресудно значење за негово разбирање и тоа ја спречува неговата редуктивна примена како нешто што исклучиво се однесува на јазикот на примитивецот.

Затоа, тие, Егејците, го прифаќаат новото име. Тоа се забележува во романот „Змиски ветер“ кога радоста на синот на Борис што научил да напише „мама“ на македонски јазик грубо ке биде прекината од лошиот домаќин Никола, кога тој ќе види дека детето пишува на неговите штици:

„Што правиш ти малечок?“

Геле ја крена главата, му се насмевна и рече:

„Учам да пишувам букви чичко Никола“, ама чичко Никола продолжи:

„Имаш ли ти тетратка?“

„Имам, рече Геле, само прво пишувам на штиците, а после во тетратката“.

Чичко Никола не издржа повеќе, цикна колку што го држи глас:

„На мајчината ти прво да пишуваш!“” и му го грабна моливот, го искрши на парчиња, па потоа откако ги пресретна со своите очи Пелагија и Добра, излезе низ вратата пцуејќи.

(Георгиевски 1969: 79)

Длабоко во себе чувствуваат и учат дека има некаква разлика меѓу нив и тукашните кога селанчињата се бесат по плетовите и гледаат во играта на дечињата во дворот размислувајќи: „Всушност нив ги чудеше дека овие деца се дојдени од зад границата, а тие зад границата си замислувале само пусти планини преполни со мечки и волци“ (Георгиевски 1969: 16).

Името Егејци за нив станува вообичаено кога се молат за работа, кога не ја добиваат и кога се истерувани, кога работат на туѓите имоти, а нивните сопствени ги напуштиле. Се навикнуваат на тоа име и на сето она што тукашните го врзуваат за нив: бездомници, голтари, искоренети, без потекло, без традиција, несигурни, сомнителни, неподобни, мрзеливи, луѓе со лоши 
карактери. На ваквите стереотипи за нив може да им се пријде од перспективата на културната интимност на Херцфелд. Според него, сврзувачките особини на еден народ кои се повод за надворешна непријатност, од една страна, генерираат внатрешна сигурност, од друга страна. Тоа значи дека токму во стигмата која им се наметнува од тукашните, тие го наоѓаат својот бедем, своето упориште во сочувувањето на својот идентитет. Токму во неа ја препознаваат и од неа ја црпат надежта дека ќ се вратат дома, таму ја препознаваат својата заедничка траума, таму го конзервираат сеќавањето. За разлика од тукашните, Егејците го носат товарот на сеќавањето за дома од онаа страна на границата. Тие овде меѓу своите се чувствуваат туѓи, се чувствуваат странци. И затоа доколку го отфрлат „егејството“ би се откажале од единствениот можен начин да го сочуваат споменот за својот идентитет, споменот за сите оние кои останале дома, на сите оние кои се расеале низ светот затоа што нивната моментална егзистенција никако не може да се сведе само на сегашноста, а да не се вклучат и другите делови од нивните семејства кои се далеку од нив.

Постојат и претстави, слики во главата за кои не се зборува. Тоа се тие невербални претстави, кои не се изречени, но се дел од оној општ идиом кој го формира идентитетот. Нашата претстава за светот се состои и од низа премолчени претпоставки независно од официјалниот дискурс. Тоа се вредности, мислења и претстави за светот кои поради својата природност и базичност не се артикулираат, тоа се тие подразбирливи вистини кои не се преиспитуваат, толку општи што од својата раширеност и прифатеност и не се чувствуваат. Од друга страна, пак, можат да бидат и свесно премолчувани и прикривани бидејќи се во спротивност со политичкиот, правниот или идеолошкиот кодекс на одреден период. Ваквото толкување на стереотипите допушта нивна поделба на вербални стереотипи и невербални стереотипи. Пандан на ваквата поделба е поделбата на неми и гласни стереотипи. На една страна се претставите кои можат и не мора да бидат препознати како стереотипи и кои се манифестираат како општи реторички места на одреден контекст, а од друга страна, доследност во невербалното означување и премолчување кое е, исто така, општо место на тој ист контекст. Виталноста на врската меѓу нив е очигледна: она што се премолчува напредува зад површината на реторичките кулиси. Под молчење не се подразбира неговорење во буквална смисла, туку она што останува зад говорењето како неартикулирано, но присутно, како толку гласен остаток од говорењето што не може поинаку да се манифестира освен со молчење. Гласното (изговореното) од друга страна секогаш го поддржува оној востановен шаблон во мислењето и постапувањето. Дијахрониски гледано немите стереотипи имаат поголема тежина од гласните. Агресивноста на гласните стереотипи е резултат на кумулативноста на немите. И додека коректноста и актуелноста на гласните стереотипи се менува, немите стереотипи никогаш не се трошат. 
Со текот на времето и низ времето Егејците и „егејството“, воопшто, добиваат одредени идеолошки содржини така што тие прераснуваат во еден своевиден мит кој може да има позитивна или негативна употреба во зависност од одреден актуелен контекст. Позитивната употреба на тој мит се гледа во фактот што тие се користат како додаток во целокупноста на македонскиот културен идентитет преку протежирање на т.н. егејски теми од реномирани уметници кои потекнуваат од тој дел на Македонија. Негативната употреба се гледа во фактот на последиците од негативните стереотипи за Егејците, за нивната неподобност за вршење јавни општествени дејности, за нивната сомнителност во одреден политички контекст. Да се биде Егеец е пожелно или непожелно зависно од политичката клима.

Таа стигма ја носат и денес. Која е причината за тоа? Зошто тие, тукашните, така ги примаат своите браќа кога им е најтешко? Одговорот веројатно го знаат другите. Меѓутоа факт е дека на историската траума на Егејците се чита целата противречност на македонската историја бидејќи тие се остаток од еден дел од ткивото на народот. Тие се сведоштво за еден дел од заедничката историја на народот, која не би требало понатаму да биде заедничка историја и која би требало да биде предадена на заборавот. Стануваат непријатно сведоштво за нарушениот континуитет во постоењето на македонската нација. Со своето постоење тие, Егејците, се знак дека македонскиот идентитет во Грција сѐ уште постои, дека тој не може да биде сведен на списите во историските архиви. Сѐ додека има Егејци од оваа страна на границата значи дека ги има и од онаа страна. Таму се нивните браќа, родители, семејни куќи, гробишта, соседи. Таму е она што Егејците внимателно го чуваат од заборавот, ги оживуваат заборавените имиња на луѓето, градовите, селата, реките, езерата, планините, полињата: „Даутица. Едно од волшебните зборови од моето детство. Една од многуте длабоко врежани слики во моето сеќавање што ги оставија во мене раскажувањата на татко ми“" (Колбе 1999: 48).

Врз егзистенцијата на Егејците се темели егзистенцијата на еден дел на македонскиот идентитет. Залог за постоењето на тој идентитет е токму стигмата содржана во зборот Егејци дури и од онаа страна на границата. Ако ги има нив, значи дека има Егејска Македонија. И колку и да звучи парадоксално, токму таа стигма ги одржа и ги спаси од заборавот бидејќи ако беа интегрирани како Македонци без никакви знаци на нивната различност, тогаш, можеби, не ќе постоеја никакви белези во идентификацијата на Македонците од егејскиот дел на Македонија, денешна северна Грција.

Стереотипите се моќни слики за другиот. Најчесто тие се создаваат кога се нема доволно информации за она за кое се донесува некој вредносен суд. Во својата дефиниција за нив, Липман инсистираше на нивната корисност во воспоставувањето ред во големата слика за стварноста како пократкиот пат до неа. Но тука го поставуваме прашањето: Дали во случајот со егејските Македонци стереотипите кои се изградија за нив беа таков востановен ред и пократок пат кон другите или беа препрека? Примерите кои ги проследивме 
за потребите на овој труд, а се еден мал репрезентативен пример на романи во нашата литература со егејска тема, го следат тешкиот и трнлив пат на егејските Македонци протерани од своите домови во нивните напори за стекнување нов дом. На тој пат мораа да се борат против стереотипите кои за нив ги изградија другите, кои за нив беа препрека на патот на нивната интеграција во новата култура. Никој од оваа страна на границата не сака да ја слушне нивната приказна. Сликата за нив оптоварена со многу предрасуди е создадена без таа да се слушне. Таа е искривена, лажна и е само превод на стварноста со помош на зборови, а задача на имагологијата е да ги открие причините за создавање на тие такви искривени слики на стварноста.

\section{Библиографија}

Георгиевски, Т. (1969). Змиски веиеер. Скопје: Македонска книга.

Колбе, Б. К. (1999). Егејци. Скопје: Култура.

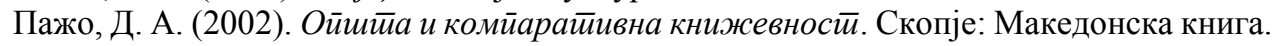
Пановски, С., Лафазановски, И. (2005). Прог̄онстиво шимо йрае. Скопје: Алфа 94.

К̈улавкова, К. (2001). Мала книжевна иееорија. Скопје: Три.

Hercfeld, Majkl (2004). Kulturna intimnost. Beograd: Krug Commerce. 